\title{
Effects of Microcredit on Crop Productivity in District Charsadda, Khyber Pakhtunkhwa
}

\author{
MUHAMMAD ROVIDAD \\ Department of Economics, Bacha Khan University, Charsadda, KP. \\ Email: rovidadm89@gmail.com
}

ALI RAZA

Department of Management Sciences, The University of Haripur, KP. Email: alirazaeco@gmail.com

SHAHID AKBAR

School of Economics, International Islamic University, Islamabad.

Email: $\underline{\text { shahidakb121@gmail.com }}$

\begin{abstract}
This study investigates the effects of microcredit on crop productivity in three villages located in district Charsadda, Pakistan. Khushali Bank, Pakistan, is an important institute that finances microcredit ranging from 15,000 to 50,000 PKR (Pakistani Rupees) per person. Sample size of 200 was choose for the analysis of this study, out of which 90 responded. Ninety farmers from three villages producing maize, tobacco, and sugarcane were interviewed. A paired sample t-test was applied to compare crop productivity in situations where microcredit was supplied with situations where it was not. Production per acre of all the three crops show a significant positive correlation with the amount of microcredit obtained from the bank. However, crop productivity remained significantly constant. Thus micro financing generally improves crop production; however, the constancy of crop productivity is explained by small credit volumes, by high interest rates, by lack of modern agricultural technology, by lack of productive ideas, and by bad monitoring through field officers of banks. The analysis of this study suggests some policy implications first, micro financing is a source of encouragement for the needy farmers, so local banks should advertise micro financing regularly. Second, the banks should increase its micro financing credit up to 200000 PKR, so that farmers can easily manage their expenses that will be more beneficial for local economy and individual profit. Third, Banks must decrease interest rate that will encourage needy farmers to take loans on regular basis.
\end{abstract}

Keywords: Agricultural Technology, Microcredit, Productivity, Khushali Bank, KP, Pakistan.

\section{Introduction}

\section{Importance of Agricultural Sector in Pakistan}

Agriculture is the backbone of Pakistan's economy contributing 21\% to its Gross Domestic Product (GDP). Nearly $70 \%$ of the total population and $60 \%$ of the rural population depend on it. Hence, agriculture is a major source of foreign exchange earnings as it provides $75 \%$ of the raw materials for the industries of Pakistan, Pakistan Bureau of Statistics (2017-18). Due to the importance of the agricultural sector, the Government of Pakistani implemented different policies and measures in order to support the development of the agricultural sector; especially it developed different programs regarding the supply of microcredits; 
because microcredit seems to be especially useful for the development not only of the agricultural but for the manufacturing sector as well.

In Pakistan, various approaches regarding microfinance strategies and adequate legislations were introduced in order to stimulate growth in the microfinance sector. In late 1990s, institutions like Khushali Bank (KB), Pakistan Poverty Alleviation Fund (PPAF), and Rural Support Programs (RSPs) were established to provide microfinance services in anticipation to alleviate poverty. In their study Ahmad et al. (2004) emphasize the importance of microfinance for the reduction of rural poverty by increasing agricultural productivity. They find a positive relationship between saving, farm expenses, crop productivity, income, and asset formation. Furthermore, Tenaw \& Islam (2009) and Saad et al. (2014) endorse the claim made by Ahmad et al. (2004) in their analysis. They investigate that provided an in time provision of microcredit loans to farmers they can maximize their profits earned through agricultural sector. Moreover, they emphasize that the farmers are well aware to reinvest their marginal profits for a sustainable future.

\section{Khushali Bank (K.B)}

As part of the strategy to alleviating poverty, the government of Pakistan established Khushali Bank in August 2000. For this initiative, the Asian Development Bank (ADB) provided US\$150 million to the government of Pakistan in order to support the microfinance sector development program (MSDP). In addition, Khushali Bank also provided US\$70 million for microfinance. (cf. Khushali Bank, 2001). It provides a credit range between US\$ 100 to US $\$ 500$ (PKR70, 000) per person, a sum beyond the usual range of microcredit and intended to endow farmers to buy capital goods and machines (Khushali Bank, 2017).

\section{Literature Review}

In their investigation about the head count ratio and microfinance Cheema and Prakash (2018), analyzed through OLS technique poverty is inversly associated with micrfinance and household size. They account a head count ratio of $56.6 \%$ in pre-microfinance circumstances, however, ratio fell significantly upto $14.5 \%$ after the implementation of microfinance loans.

Ali et al. (2015) conducted an empirical research in the district of Malakand, Pakistan, on quality of life of the poorest section. Their study focused mainly on business development as a main source for income generation of the microfinance borrowers. The results revealed that the utilization of micro loans principally depend upon the education level, age, experience, and the number of times repondents received microfinance. Accordingly, they claim that the more educated and experienced borrowers are the more productively they use the credit. Similarily, Asghar (2012), conducted a study in district Gujrat, Pakistan by selecting a sample of 316 microfinance borrowers. The study investigated mocrofinance services provided by Punjab Rural Support Program (PRSP) and found that a $1 \%$ increase in microfinance services will bring upto $79 \%$ change in the incomes of borrowwers. The author also regressed education levels and incomes of borrowers and ascertain that with a 1 year increase in education level brings $26.3 \%$ increase in income.

Cheema (2011) compared Pakistani provinces in terms of poverty head count ratio, and the respective role of microfinance in conbating poverty. Using Pakistan's Social and Living statndard Measurment (PSLM) data, author estimates that microfinance is more inversly related with poverty in manufacturing areas. Accordingly, he concludes that microfinance is more productive in the province of Punjab, due to the reason that this province is more prone towards manufacturing.

The study by Mudassar (2000) investigates the role of the micro-enterprise development program of Sarhad Rural Support Program (SRSP). In this study he shows that $53 \%$ of respondents use credit for the development of enterprises, $36 \%$ for livestock and $11 \%$ availed the credit for buying agricultural inputs. 
$53 \%$ of the sample had difficulties in obtaining credit and majority complained about the insufficiently small credit amount and the high interest rate. According to Mudassar (2000) an increase in the volume of credit offered per customer and a reduction in interest rates will help farmers to increase agricultural performance. Kamran (2002) in his study shows that microcredit increases interest in modern farming techniques and its applications. As a consequence poor farmers develop ideas to use better and refined inputs so as to increase their production. The efficient use of microcredit enables farmers to medicate and vaccinate animals properly. Furthermore, increases in agricultural production results in an increase of the farmer's income; Gallup et al. (1997) ascertain that a one percent (1\%) increase in per capita agricultural output yields a $1.61 \%$ increase in the poorest farmer's income. Likewise Thirtle et al. (2001) find that a $1 \%$ increase in agricultural yield radically reduces the number of people living on 1 US dollar per day. The aforementioned studies indicate that farmers having access to financial services invest microcredit efficiently and are capable of overcoming poverty. Javed et al. (2006) report that microcredit offered by the National Rural Support Program (NRSP) is most important for empowering women to set up small scale enterprises and to increase their living conditions. On the basis of a questionnaire Waheed (2009) investigates the importance of microfinance for reduction of poverty in Pakistan and finds that microcredit improves income of respondents by increasing crop production, and by enhancing animal breeding and other small enterprises. Similar results were also found by the study of Raza et al. (2020). The authors are of the view that loan investment can help to improve living standard of individuals and is beneficial for local economy.

\section{Crop productivity and Microcredit}

Government programs not only aimed at developing the agricultural sector of Pakistan by implementing programs in order to increase output but to increase crop productivity. The studies reviewed do not investigate the effect of micro credit and crop productivity. Accordingly this study investigates the effect of microcredit and crop productivity for a special area.

Diewart (1992) defines productivity as output-input coefficient changing through time and shows that output increases with additional financial support. However his study does not investigate the effects of microcredits on crop productivity. Khan (1994) in his study shows that in developed countries, an increase in agricultural production is due to the provision and excessive use of credit by farmers along with the application of modern farming techniques. Using credit, it is possible to increase farm efficiency that improves the net farms revenue by increasing agricultural productivity. In addition credit helps farmers to adjusting to adverse conditions and seasonal/annual fluctuations in incomes and expenditures. It further helps farmers in acquiring modern farming techniques and to improve development in general. Thus better credit facilities play an integral role in the modernization and commercialization of rural economies. Chavan (2002) finds that microcredit is provided for entrepreneurs unable to qualify for traditional bank loans. In a study on the Dir Area Support Project (DASP) Nazir et al (2011) find that crop production significantly increases if financial support is offered. Due to that successful project farming production area increased by $23 \%$ (from 262.61 to 323.33 acres) and cropping pattern diversified by planting new kinds of vegetables like radishes, turnips and carrots in the rabbi season. (Rabbi or Rabi Season: A cropping season in which crops are sown in winter and harvest in spring). However, many farmers were not capable of participating in that project because they simply were not aware of its existence. Accordingly, the authors recommend to improve information for farmers regarding the availability of microcredit projects and to reduce interest rates for loans. The study of Raza et al. (2020) contributes that investment loan improves the income and economic growth of individuals.

\section{Research Methodology}

The objectives of this study are to study the effects of micro-credit on crop productivity and to recommend policy measures in order to improve the micro-credit program of Khushali Bank. 


\section{Agricultural Productivity}

Productivity is defined as; a ratio between output and input in a particular production situation; it is also called output-input coefficient. It is shown that additional financial support increases the level of output but not productivity. However, agricultural productivity is rather low and therefore the government has implemented several policies to increase productivity by initiating financial support programs, introducing new agricultural technologies and by assessing the farmers' performance on a regular basis (Abro et al., 2010).

\section{Universe of Study}

Charsadda district is located in the northwest Pakistan and has an area of $996 \mathrm{~km}^{2}$. There are three tehsils ${ }^{1}$ and 46 union councils ${ }^{2}$ in this district. The majority of the population in this area is living below the poverty line with agriculture being the dominant profession and major source of income to go with foreign remittances from the Middle East. The present study is based on Three villages; Marghan, Chail and Qamar Khan Kaley of Shodag union council, Tehsil Tangi of Charsadda as Khushali Bank provides a considerable volume of microcredit in these villages.

\section{Sampling and Sample Size}

About 200 households received microcredit from Khushali Bank for different developmental purposes including agricultural productivity, livestock development and small enterprise development etc. Proportional allocation technique was used to select a sample of 90 respondents defined as:

$$
n i=\frac{N i}{N} \times n
$$

Where, ni is total number of sampled farmers/ beneficiaries in $\mathrm{i}^{\text {th }}$ Village, $\mathrm{n}$ is required sample size, $\mathrm{N}$ is total number of beneficiaries in the research area and $\mathrm{Ni}$ is total number of farmers/ beneficiaries in $\mathrm{i}^{\text {th }}$ Village. The sample selected from each village of the study area is given in the following Table 1.

Table 1: Distribution of Sampled Beneficiaries in the Study Area

\begin{tabular}{|c|c|c|}
\hline Villages & No. of Respondents & Sample Size \\
\hline Marghan & 80 & 36 \\
\hline Qamar Khan kaley & 65 & 29 \\
\hline Chail & 55 & 25 \\
\hline Total & 200 & 90 \\
\hline
\end{tabular}

Source: Field survey

\section{Data Collection}

This is a questionnaire based research investigation, which is constructed regarding cropping pattern, cost of production, crop productivity, and credit and input utilization. Accordingly, the interviews are conducted based on personal observations and advisor's suggestions. In order to obtain truthful data; moreover, regarding w.c and w.o.c situations, respondents were interviewed in the absence of the field officer of the Khushali Bank.

\footnotetext{
${ }^{1}$ Tehsil: An administrative division of a district mostly used in Pakistan and India.

${ }^{2}$ Union Council: Union council in Pakistan is an elected local government body.
} 


\section{Constructed Hypothesis and Data Analysis}

The conjectural hypothesis is:

$\mathbf{H}_{\mathbf{0}}$ : There is no significant effect of microcredit on crop productivity:

H1: There is significant effect of microcredit on crop productivity.

With respect to the yield of all the three subject crops (maize, sugarcane and tobacco) the hypothesis $\mathrm{H}_{0}$ and $\mathrm{H}_{1}$ are tested. A paired t-test is applied in order to compare the effects of microcredit on crop yields by analyzing situations w.c and w.o.c. The following formula for the paired sample t-test is used:

$$
t=\frac{\bar{d}}{\sqrt{s^{2} / n}}
$$

Where $\bar{d}$ is the mean difference between two samples, $s^{2}$ is the sample variance, $n$ is the sample size and $t$ is a paired sample t-test with $n-1$ degrees of freedom.

\section{Results and Discussion}

\section{Criteria of Khushali Bank`s Microcredit}

In the study area, Khushali Bank offered one-year loans from $\mathrm{PKR}^{3}$ 10,000 to PKR 25,000, at an interest rate of $30 \%$. The bank also provides loans for a very short term of three (3) and six (6) months.

Table 2: Credits Provided for Maize, Sugarcane and Tobacco

\begin{tabular}{|c|c|c|c|}
\hline Crop & Credit PKR. & Tenure & Interest Rate \\
\hline Maize & $10,000-15,000$ & 0ne year & $30 \%$ \\
\hline Sugarcane & $20,000-25,000$ & 0ne year & $30 \%$ \\
\hline Tobacco & $20,000-25,000$ & 0ne year & $30 \%$ \\
\hline
\end{tabular}

\section{Effects of Microcredit on Production Cost, Total Output, and Net Revenue of Maize}

Table 2, represents the data regarding costs, output, and revenue details for maize. The major cost components including land preparation, seed cost, labor cost, fertilizer, and farmyard manure, pesticide and land rent are included. Table 2 shows that for maize crop, the average cost per acre for land preparation is PKR.3276 w.o.c; however, it increases to PKR.4333 w.c.

Similarly seed cost and labor cost per acre w.o.c is PKR.1401 and 7516, respectively, which increases to PKR.2063 and 9977 in the same order. Fertilizer costs and farmyard manure costs in situation w.o.c and w.c are PKR.12003 and 15575. Pesticide costs per acre increases from PKR.1500 to 2199. Land rent did not change in situation w.o.c and w.c. It is calculated on the opportunity cost basis.

The data in Table 3 also show that output per acre is $1828 \mathrm{~kg}$ w.o.c, and increases to $2393 \mathrm{~kg}$ w.c. Similarly, net revenue per acre increases from PKR.58574 w.o.c to PKR.76576 w.c. The values for the tratio and for the $\mathrm{P}$ value show that all these variables (seed cost, labor cost, fertilizer and FYM cost and pesticide cost) increase significantly. Also Table 3 shows that seed costs increased exceptionally. This is due to the farmer's substitution of credit financed expensive hybrid seed for inexpensive traditional seed.

3 PKR: Abbreviated from Pakistani Rupee/ Currency Unit of Pakistan, also represented by 'Rs'. 
Table 3: Cost of Inputs, Output and Net Revenue Without and With Credit (Respondents of Maize).

\begin{tabular}{|c|c|c|c|c|c|c|c|c|}
\hline $\begin{array}{c}\text { Variables (Cost) } \\
\text { PKR }\end{array}$ & \multicolumn{3}{|c|}{ Without Credit } & \multicolumn{2}{c|}{ With Credit } & \multirow{2}{*}{ t-ratio } & P-value \\
\cline { 2 - 8 } & Mean & SD & CV & Mean & SD & CV & & \\
\hline Land Prep cost & 3276 & 613.4 & 20.6 & 4333 & 308.8 & 9.5 & 2.2 & 0.03 \\
\hline Seed Cost & 1401 & 18.3 & 4.4 & 2063 & 166.5 & 5.6 & 82.7 & 0.00 \\
\hline Labor Cost & 7516.8 & 1718.1 & 22.9 & 9977.6 & 1472.9 & 14.7 & 8.4 & 0.00 \\
\hline $\begin{array}{c}\text { Fertilizer, FYM } \\
\text { Cost }\end{array}$ & 12003.3 & 1805.5 & 22.2 & 15575.6 & 1349.3 & 12.1 & 10.1 & 0.00 \\
\hline Pesticide Cost & 1500 & 462.7 & 52.2 & 2199.1 & 296.9 & 15.6 & 9.5 & 0.00 \\
\hline Land Rent & 12000 & 0 & 0 & 10000 & 0 & 0 & & \\
\hline Total Cost & 37697.1 & 3223.6 & 122.4 & 44148.3 & 2186.9 & 5.7 & 20.1 & 0.00 \\
\hline Yield (Kgs) & 1828.4 & 136.5 & 7.9 & 2393.1 & 125.6 & 5.2 & 33.6 & 0.00 \\
\hline $\begin{array}{c}\text { Net Revenue } \\
\text { (PKR) }\end{array}$ & 58754 & 3139.7 & 181.6 & 76576 & 2888.2 & 54.1 & 33.6 & 0.00 \\
\hline
\end{tabular}

$\mathrm{SD}^{*}$ represents Standard deviation, $\mathrm{CV}^{* *}$ indicates coefficient of variation $=(\mathrm{SD} / \mathrm{Mean}) * 100$, ${ }^{*}$ All the factors except credit are assumed constant

The results for sugarcane and tobacco are quite similar to those regarding maize. However, unlike to the case of maize, the fertilizer costs for sugarcane and tobacco has witnessed high increase in situation without and with credit. Again this is to be explained by the substitution of high quality for low quality fertilizers. For more details, compare Table 3 and 4, which are, constructed analogues to Table 2.

Table 4: W.C and W.O.C Effects on Average Cost of Inputs, Yield and Net Revenue Sugarcane Growers

\begin{tabular}{|c|c|c|c|c|c|c|c|c|}
\hline \multirow{2}{*}{$\begin{array}{l}\text { Variables (Cost in } \\
\text { PKR) }\end{array}$} & \multicolumn{3}{|c|}{ Without Credit } & \multicolumn{3}{|c|}{ With Credit } & \multirow{2}{*}{ t-ratio } & \multirow{2}{*}{ P-value } \\
\hline & Mean & SD & $\mathrm{CV}$ & Mean & SD & $\mathrm{CV}$ & & \\
\hline Land Prep cost & 15306 & 1794.9 & 17.4 & 18547 & 1264.6 & 10.71 & 6.1 & 0.00 \\
\hline Seed Cost & 12680 & 1939.5 & 20.03 & 14260 & 1631 & 14.48 & 6.9 & 0.00 \\
\hline Labor Cost & 25203 & 3660.6 & 21.2 & 28666 & 2875.6 & 16.4 & 0.6 & 0.60 \\
\hline Fertilizer,FYM Cost & 20463 & 1901.4 & 11.54 & 31331 & 3322.5 & 12.15 & 21.7 & 0.00 \\
\hline Pesticide Cost & 4586 & 539.9 & 20.8 & 6824 & 425.4 & 20.8 & 2.8 & 0.12 \\
\hline Final Cost & 27003 & 1706.8 & 10.66 & 37770 & 1788.4 & 10.06 & 5.9 & 0.00 \\
\hline Land rent & 24537 & 1279.3 & 5.2 & 30000 & 0 & 0 & 23.4 & 0.00 \\
\hline Total Cost & 129778 & 5241 & 5.5 & 167398 & 4649.6 & 4.05 & 28.2 & 0.00 \\
\hline Yield (Kgs) & 2115.3 & 139.3 & 7.27 & 2688.6 & 183.8 & 6.83 & 24.7 & 0.00 \\
\hline Net Revenue & 208482 & 8358.1 & 7.49 & 243432 & 10110.3 & 7.04 & 18.6 & 0.00 \\
\hline
\end{tabular}

Table 5: W.C and W.O.C Effects on Average Cost of Inputs, Yield and Net Revenue Tobacco Growers

\begin{tabular}{|c|c|c|c|c|c|c|c|c|}
\hline Variables (Cost in PKR & \multicolumn{2}{|c|}{ Without Credit } & \multicolumn{2}{|c|}{ With Credit } & \multirow{2}{*}{ t-ratio } & \multirow{2}{*}{ P-value } \\
\cline { 2 - 8 } & Mean & SD & CV & Mean & SD & CV & & \\
\hline Land Prep cost & 16949.5 & 1364.4 & 15.5 & 20867 & 1275 & 12.9 & 4.2 & 0.00 \\
\hline Seed Cost & 1000 & 0 & 0 & 1600 & 0 & 0 & & \\
\hline Labor Cost & 50725 & 4167.2 & 11.6 & 67025.3 & 3882.5 & 10.4 & 4.4 & 0.00 \\
\hline Fertilizer,FYM Cost & 24216 & 1609 & 9.3 & 35433.3 & 2013.2 & 6.4 & 51.6 & 0.00 \\
\hline Pesticide Cost & 8434 & 476.5 & 17.4 & 12080 & 608.9 & 14.9 & 11.7 & 0.00 \\
\hline Final Cost & 81030 & 2944 & 9.48 & 98207.6 & 2753.2 & 8.5 & 6.2 & 0.00 \\
\hline Land rent & 30000 & 0 & 0 & 30000 & 0 & 0 & & \\
\hline Total Cost & 212354.5 & 5710.5 & 46 & 265213.2 & 5605 & 3.9 & 28.2 & 0.00 \\
\hline Yield (Kgs) & 1518.5 & 61.44 & 4.6 & 1630.5 & 83.9 & 5.1 & 22.1 & 0.00 \\
\hline Net Revenue & 353353 & 7373.9 & 4.8 & 405487 & 10906.3 & 5.3 & 29.8 & 0.00 \\
\hline
\end{tabular}




\section{W.C and W.O.C Effects of Microcredit on the Productivity of Maize, Tobacco and Sugarcane}

Table 6 displays no significant change in crop productivity in situation without and with credit in the productivity of all the three crops. The productivity of maize remains constant $(0.063)$ in situation without credit; sugarcane crop productivity is 0.02 w.o.c and 0.02 w.c; and for tobacco crop productivity it is 0.011 and 0.11 without and with credit. Hence in case of all the three crops null hypothesis $\left(\mathrm{H}_{0}\right)$ is to be accepted. Table 6: W.C and W.O.C Effects of Microcredit on Maize, Sugarcane and Tobacco Crop Productivity

\begin{tabular}{|c|c|c|}
\hline Crop & $\begin{array}{c}\text { Productivity without credit } \\
\text { Productivity=output/input }\end{array}$ & $\begin{array}{c}\text { Productivity with credit } \\
\text { Productivity=output/input }\end{array}$ \\
\hline Maize & 0.063 & 0.063 \\
\hline Sugarcane & 0.020 & 0.020 \\
\hline Tobacco & 0.011 & 0.011 \\
\hline
\end{tabular}

Table 6, shows in contrast to productivity which basically remains constant input cost increased in general. Accordingly it can be concluded that there exists no significant effects of microcredit on crop productivity. Presumably this insignificant difference in crop productivity is due to the small volume of credit provided as well as to the high interest rate of $30 \%$.

\section{Conclusions and Recommendations}

This study shows that credits provided by Khushali Bank did not have the desired effects on crop productivity. Although the level of output increases in situation w.c and net revenues increase as well; however crop productivity did not increase. The respondents were facing time consuming transport, acquiring a sufficiently large credit, high service and interest rates to go with obtaining credit in general as their major problem. These factors perhaps explain why crop productivity remains constant. In order to improve the performance of agricultural activities and to counter the obstacles in obtaining credit the following suggestions are made.

1) Decrease interest rates. (2) Increase credit amount above PKR 100,000. (3) Extension agents need to inform the farmers on a regular basis about credit program. (4) Supervision and monitoring of the utilization of credit in efficient use of inputs. (5) In case of a failure of an enterprise its repayment period needs to be extended. (6) Credits ought to be provided for those farmers who have a legal demand for it.

\section{References}

Abro, A., \& Sadaqat, M. (2010). Poverty Alleviation through diversifying towards high value crops in Pakistan. Int. J. Buss. Mgt. Eco. Res, 1(1), 1-8.

Adjei, J. K., Arun, T., \& Hossain, F. (2009). The role of microfinance in asset building and poverty reduction: The case of Sinapi Aba Trust of Ghana. Brooks World Poverty Institute, University of Manchester.

Ahmad, S. Naveed, S.M. \& Ghafoor, A. (2004). Role of Microfinance in Alleviating Rural poverty: A case study of Khushhali Bank Program in Rahim Yar Khan Pakistan. International Journal of Agriculture and Biology, 12(7): 426-428.

AKAM. (2008). Annual Report, Agha Khan Agency for Microfinance. 1-3 Avenue de la Paix 1202 Geneva, Switzerland.

Akram, M., \& Hussain, I. (2011). The role of microfinance in uplifting income level: a study of District Okara-Pakistan. Interdisciplinary journal of contemporary research in business, 2(11), 83-94.

Ali, A., \& Alam, MA (2010). Role and performance of microcredit in Pakistan.

Andrews, M. (2006). Microcredit and Agriculture: How to make it work. Mennonite Economic Development Associates (MEDA), Canada. 
Asghar, N. (2018). Micro financing for poverty reduction: An empirical study of rural areas of Tehsil Gujrat-Pakistan. International Journal of Advances in Management and Economics, 1(4), 14-19.

Chavan,P. (2002). The Role of Microcredit on Poverty Reduction by Using Comparative Analysis Approach. Economic and Political Weekly, 37(10), 955-965

CHEEMA, A. R., \& PARKASH, R. (2018). Role of microfinance in poverty alleviation in rural areas of district sargodha, Pakistan. Pakistan Journal of Applied Economics, 28(Special Issue), 111-128.

Cheema, A. R., \& Sial, M. H. (2014). Poverty and its determinants in Pakistan: Evidence from PSLM 2010-11. Journal of Poverty, Investment and Development, 5(3), 1-16.

Chodhury, A. (2009).Microfinance as a Poverty Reduction Tool, A Critical Assesment.DESA Working Paper No.8

Diewart, W. E. (1992). The measurement of productivity, Bulletin of Economic Research, 44(3), 163-98.

Effa, D. A., \& Herring, D. R. (2005). Micro finance support to rural women farmers in Ghana: a case study of the Ga district of the greater Accra region, Ghana (Doctoral dissertation, University of Arkansas, Fayetteville).

Federal Bureau of Statistics (2017), Govt of Pakistan.

Gallup, J., Radelet, S., \& Warner, A. (1997). "Economic Growth and the Income of the poor." CAER II Discussion Paper. Cambridge, MA: HIID .

Kaleem, R. \& T. Salahuddin. (2011).Micro Financing of NGOs and Government: Collaborative Impact on Poverty Eradication. Information Management and Business Review, 2 (2), 81-91.

Khan, R. A. R. (1994). Farm loans recovery problem in Pakistan: its possible solution. The Pakistan Development Review, 33(4), 837-843.

Nazir, M., D. Jan, M. Sajjad, A. U. J., \& G. Ali. (2011). Role of micro credit advanced by Dir area support Project in the development of agriculture. Interdisciplinary Journal of Contemporary Research in Business. 3(8), 705-717.

Raza A., Azam M. \& Tariq M. (2020): The Impact of Greenfield-FDI on Socio-Economic Development of Pakistan. HSE Economic Journal, 24(3), 415-433.

Raza, A., Khan, M. A. \& Tariq, M. (2020): A Panel Data Investigation of Greenfield Investment on the Welfare of African Developing Countries. International Review Social Sciences, 8(8), 41-53.

Saad, A., Waraich, I. A., \& Ijaz, M. (2014). Socio-economic effects of microfinance on agricultural sector: an analysis of farmer's standard of life in Multan. International Review of Management and Business Research, 3(3), 1671.

Sengupta, R., \& Aubuchon, C. P. (2008). The microfinance revolution: An overview. Federal Reserve Bank of St. Louis Review, 90(January/February 2008).

Tenaw, S., \& Islam, K. Z. (2009). Rural financial services and effects of microfinance on agricultural productivity and on poverty. University of Helsinki Department of Economics and Management (Discussion Papers series), 1, 28.

Thirtle, C., Irz, X., Lin, L., McKenzie-Hill, V., \& Wiggins, S. (2001). Relationship between changes in agricultural productivity and the incidence of poverty in developing countries. report commissioned by the Department for International Development, London. www.khushhalibank.com.pk/about_us/index.php?param=1 